\title{
Geochemical transfers associated to peridotite carbonation: Results from drilling the listvenite-metamorphic transition in the basal megathrust of the Semail Ophiolite (Oman Drilling Project Hole BT1B)
}

MARGUERITE GODARD ${ }^{1}$, ELLIOT CARTER ${ }^{2}$, JUAN CARLOS DE OBESO ${ }^{3}$ AND PETER KELEMEN ${ }^{4}$

${ }^{1}$ Géosciences Montpellier, CNRS, U. Montpellier

${ }^{2}$ Department of Geology, Trinity College Dublin

${ }^{3}$ University of Calgary, Department of Geoscience

${ }^{4}$ LDEO, Columbia University

Presenting Author: marguerite.godard@umontpellier.fr

The formation of carbonated peridotites, ophicarbonates (serpentinite-carbonate assemblages) and listvenites (quartzcarbonate assemblages), is commonly observed along suture zones. This hydrothermal process is an important component of carbon cycling but its impact remains poorly studied for other chemical elements. During ICDP Oman Drilling Project, the transition from the base of the Semail ophiolite to the underlying metamorphic sole was drilled at Hole BT1B (Wadi Mansah). We analyzed the bulk major, volatile and trace element compositions of 65 variously carbonated peridotites (serpentinites, ophicarbonates, and (fuchsite-bearing) listvenites) and 31 metabasalts and sediments collected from recovered cores and the Wadi Mansah area, with the aim to better constrain chemical transfers associated to peridotite carbonation along the ophiolite basal thrust.

The listvenite series record the formation of listvenites after a serpentinized peridotite protolith: this process is marked by $\mathrm{CO}_{2}$ addition and $\mathrm{H}_{2} \mathrm{O}$ removal $\left(\mathrm{CO}_{2}=21.3-43.2\right.$ wt.\%; $\mathrm{H}_{2} \mathrm{O}<0.1$ wt. $\%$ in listvenites). Their bulk geochemistry is highly variable at the meter scale yet, on average, it is close to that of the refractory peridotites of the Semail mantle section for most major and lithophile trace elements (e.g., $\mathrm{Al}_{2} \mathrm{O}_{3}=0.1-0.8$ wt.\%; $\mathrm{Yb}=0.05$ $0.2 \times$ CI-chondrite), except of the fuchsite-bearing listvenite domain that has compositions overlapping that of the more fertile, often amphibole-bearing, basal lherzolites (e.g., $\mathrm{Al}_{2} \mathrm{O}_{3}=$ 0.9-2.2 wt.\%; $\mathrm{Yb}=0.2-1 \quad \mathrm{x}$ CI-chondrite). This suggests preservation of the peridotite protolith geochemistry in spite of extensive peridotite carbonation. All samples are however enriched in fluid mobile elements (FME) compared to the composition of the Semail peridotites (up to $\sim 10^{3}-10^{4} \mathrm{x} P \mathrm{PM}$ ). They have concentrations similar to the metamorphic sole and/or associated metasediments for elements such as $\mathrm{Cs}, \mathrm{Sr}$ and $\mathrm{Ca}$ and sometimes even higher for elements such as $\mathrm{Pb}, \mathrm{Li}, \mathrm{As}$, and $\mathrm{Sb}$ (e.g., Li up to $130 \mathrm{ppm}$; As up to $170 \mathrm{ppm}$ ). We also observe a decoupling between $\mathrm{Sr}-\mathrm{Ca}$ enrichments and for other FME, indicating interactions with several batches of $\left(\mathrm{CO}_{2}\right.$-rich) fluids originating in neighboring lithologies or deeper along the basal thrust. These results suggest that peridotite carbonation reactions could represent one of the major trap-and-release mechanisms for water and FME along convergent margins. 